\title{
Analysis of the Anti Corruption Campaign for Engagement and Action on Social Media
}

\author{
${ }^{1}$ NENI YULIANITA, ${ }^{2}$ NURRAHMAWATI, ${ }^{3}$ ANNE MARYANI \\ 1,2,3 Universitas Islam Bandung, Jl. Tamansari No. 24-26 Bandung, Indonesia. \\ correspondence author: ${ }^{1}$ yulianita.neni@gmail.com
}

\begin{abstract}
The problem of corruption in Indonesia is at an alarming point. Corruption often occurs in fairly complex public services, such as licensing issues, procurement of goods and services, etc. Those kinds of services are considered 'profitable' which triggered the opportunities for corruption. This problem needs to be overcome through a new solution that can become the best. The object of research is the anti-corruption campaign conducted by the Corruption Eradication Commission (KPK) through Instagram and Facebook. The purpose of this research is to find out, analyze, and discuss the involvement and actions of anti-corruption campaigns on social media Facebook and Instagram. This research uses a survey method through a descriptive-analytic study approach. The data is taken through a questionnaire by comparing Instagram and Facebook. The result shows that the campaign through Facebook is generating more active comments with a more flexible duration of time and diverse targets than Instagram. This research can be a stimulus to bridge public awareness of the importance of anti-corruption. A further implication is that people will get a better awareness of the importance of anti-corruption knowledge and are able to spread it to the public.
\end{abstract}

Keywords: anti-corruption, campaign, facebook and instagram

\section{Introduction}

The latest survey in 2018 conducted by the Political and Economic Risk Consultancy (PERC) showed that the three countries of Indonesia, Vietnam, and Cambodia were the countries with the worst bureaucratic performance in Asia. While Singapore and Australia were the most efficient. PERC considered the poor performance of the bureaucracy in these three countries was not only about the treatment to their citizens but also foreigners. Bureaucratic inefficiency and perception of corruption are considered as factors that prevent foreign investment. Furthermore, based on the data obtained, it is stated that although the efforts to fight corruption have increased from year to year, however, the number of corruption practices also increased. Transparency International (TI) discovered that the score of Indonesia's Corruption Perception Index (CPI) in 2015 was increased to 36 and took the position of the 88th rank out of 168 measured countries.
Indonesia's 2017 Corruption Perception Index (CPI) score was 37 and ranked 96 out of 180 countries surveyed. Indonesia's CPI score had the same point as in 2016. The CPI score is in the range of $0-100.0$ means the country is perceived to be very corrupt, while a score of 100 means a country is clean of corruption ("CPI-2017: Menera Korupsi di Tahun Politik - Transparency International Indonesia," n.d.). Indonesia Corruption Watch (ICW) was ranked 26th in the 2019 "Global Go To Think Tank Index" based on a report by The Lauder Institute of the University of Pennsylvania, USA. In the report, ICW again included in the category of "Top Transparency and Good Governance Think Tanks". Compared to 2018, ICW's position rose by one rank (previously 27 ) to 26 from 67 global organizations. Not only that, for the category of "Think Tank to Watch" ICW also ranked 65 out of 112 institutions in various countries ("ICW Kembali Menempati Peringkat Dunia dalam 'Global Think Tank Index 2019,'" 2020). Nonetheless, the number of corruption cases are getting

Received: 2020-03-28, Revised: 2020-05-05, Accepted: 2020-06-03. 
increased... The punishment given does not provide a deterrent effect for the perpetrators and is incompatible with the losses obtained. Ulya stated that the punishment was not comparable to the tremendous national financial loss that had an impact on economic growth and not giving detriment impact on the subjects (Ulya, 2016). The OECD (Organization for Economic Co-operation and Development) reported that a $1 \%$ increase in corruption will reduce economic growth by $0.73 \%$ and the impact of corruption will result in an additional $10 \%$ cost in business (Widyaningrum, 2018). Corruption continues to spread at various levels of the community, even shown by public officials at all levels. The Corruption Eradication Commission (KPK) has captured many corruptors in Indonesia. As it is governed by the law (Republic Act, 28/1999), every government official must avoid corruption. The state officials should not commit acts of corruption, collusion, and nepotism; even though corruption, in particular, cannot be eradicated (Dirwan, 2016).

A strong structure is needed to ward off corruption in Indonesia as Irawati (2013) said corruption has a structure and has become a very strong culture in the Indonesian bureaucracy. The bureaucracy system which should provide main support in a modern state, in practice becomes a source of problem and obstacles in the administration of the state system (Irawati, 2013). Various obstacles that provide opportunities for corruption must be trimmed. Different forms of corruption include bribery, financial embezzlement by public officers, extortion by public officials, cheating, procurement with guaranteed benefits, and gift-giving. Such acts are done and intended for state officials who cause losses to state finances (Habibi, 2018). Corruption has a huge impact on various aspects of life, for example, it negatively affects the efficiency of public spending, reduces budget revenues and increases its deficit, impedes foreign direct investment, reduces the effectiveness of international assistance, and hinders economic development (Savchenko \& Subbot, 2018).

Corruption can be prevented starting from the lowest level of a unit in society, such as families who try to educate about honesty to their family members and then implement it at a broader level in society in various contexts and situations. A core concept of corruption is a moral and ethical dimension that may translate into legal provisions in various ways. Abuse of entrusted power tends to be a problem that happened all over the world. The effort to combat corruption can be based on different rationales, either the drive to get greater aid effectiveness and domestic legitimacy of aid and/or an understanding of corruption as ethically undesirable (Dachroni et al., 2017). Corruption has an extensive effect on people's lives, as stated by Setiadi that corruption is a bad act (such as embezzlement of money, bribes, etc.). Corruption is very dangerous for people's lives in the aspect of social, politics, bureaucracy, economy (Setiadi, 2018). From this opinion, it is clear that corruption is damaging the life of the nation, especially the Indonesian people. Therefore, it is important to do prevention efforts in various ways. One of the ways is through anti-corruption campaigns both directly and indirectly through mass media and social media. This prevention is to minimize acts of corruption, especially for the younger generation as the next generation of the nation. One of the most dangerous effects of corruption is the destruction of the younger generation. In a society where corruption has become a habit, children grow up with antisocial personalities, and then the younger generation will consider corruption as a normal (or even cultural) way of life so that their personal development becomes accustomed to dishonesty and irresponsibility (Setiadi, 2018).

Social media exists like a group of countries or communities, in which some various ethics and rules bind its users. This rule exists because the technology device is a machine that is connected online or can emerge due to the interaction between fellow users (Nurfitri, 2017). Social media has the benefits to interact, build identity, and build a reputation so that social media can be used as a medium to communicate the information and educate the public regarding community and government programs, including corruption. Social media is one of the products of technological development that cannot be separated from people's lives. Social media offers convenience for the community in various aspects, such as the easier way to obtain and convey information, express themselves and gain social and economic benefits (Amin, Dziqie, Alfarauqi, \& Khatimah, 2017). Social media can also involve the public in the information dissemination about the program on corruption. It is done to build a good understanding in the community about eradicating corruption and 
create a positive image for the Corruption Eradication Commission (KPK). Media usage in daily life, especially digital media, has attracted a lot of attention due to the everincreasing opportunities created by today's mediated environment for encouraging social participation (He, Huang, Li, Zhou, \& Li, 2020). Through social media, it is hoped that corruption can be reduced by providing an understanding of the dangers of corruption so that people understand and then disseminate the knowledge to others. Social media are Internet-based channels that allow users to intentionally interact and selectively selfpresent, either in real-time or delayed, with both broad and narrow audiences who derive value from user-generated content and the perception of interaction with others (Carr \& Hayes, 2015). The potential of social media is huge because it has characteristics that can build public engagement with institutions through intensive communication using features provided by social media platforms. As it is explained by Skoric et al. that social media use generally has a positive relationship with engagement and its three sub-categories: social capital, civic engagement, and political participation. More specifically, we find a small-to-medium scale of positive relationships between expressive, informational, and relational uses of social media and the above indicators of citizen engagement (Skoric, Zhu, Goh, \& Pang, 2015). Social media has become part of the lifestyle of urban people whose lives cannot be separated from the use of social media to search for information and social relations. In other words, social media are now part of our daily routine. People wake up in the morning and open their accounts to check out the news, friends, and family life or to create content (Perreault; Marie-Catherine: Mosconi, 2018). Social media has different characteristics and different user segments; each of which has its own features, unique rules, and variations. Types of social media exist are Facebook (a social network), Snapchat (an instant photo messaging application), Instagram (a photosharing application), Twitter (a microblogging application), LinkedIn (a business-and employment-oriented social networking service), GoogleC (an interest-based social network), and Pinterest (a "catalog of ideas" or photo-sharing website) which all represents different types of social media with unique architectures, cultures, and norms (Voorveld et al., 2018). Some social media users like Twitter, Instagram, Facebook because they have features that can support users to connect and collaborate. It is in line with Majmundar et al.'s statement who stated that social media such as Twitter, Instagram and Facebook are viewed as online services that allow communities to collaborate, connect, and interact with user-generated or shared content that is modified (Majmundar, Chou, Cruz, \& Unger, 2019).

Corruption eradication programs can be socialized through campaign activities via various media directly. Campaigns are one form of communication activities carried out in a planned manner to create certain impacts on the public. The activity is generally organized by an institution, both government and private (Khoerunnisa, Rissa; Abidin, Yusuf Zaenal; Ma'arif, 2018). The success of achieving campaign objectives is largely determined by planning. Campaign aspects (actors, messages, channels, targets, and strategies) are chosen in a planned and measured manner so that objectives can be achieved (Permana, 2016). Likewise, the anti-corruption campaign program must be planned in such a way as to include aspects of sources, media messages, and delivery techniques so that the objectives of the campaign can be achieved. The entire contents of the campaign program (campaign content) can be directed to equip and influence aspects of the voters' knowledge, attitudes, and skills as main prerequisites for voting behavior change (Arianto, 2015). The purpose of the anti-corruption campaign must be achieved in stages and focus on specific goals, as it is stated by Setiawan et al. saying that public relations campaigns should focus on one goal to be achieved, be it awareness, interest, desire, and attitude. But it is not possible if the campaign wants to achieve two objectives, such as changing behavior and awareness. But the goal of this campaign should be to start from building awareness to changing behavior gradually. In addition, the objectives of the campaign must be measurable so that they have a clear picture (Setiawan \& Fithrah, 2018).

The anti-corruption campaign is carried out on the social media of Facebook by the reason that Facebook has a huge number of users so that many people can accept the information. Facebook has been the most popular platform with more than 2 billion users worldwide and 1.37 billion of whom utilize the site daily (Dragseth, 2019). Like and share Facebook posts, and like the characters in the Facebook posts are the major outcomes of social media engagement 
(Wang, Kim, Xiao, \& Ju, 2017). Nowadays, the use of social networking sites as a medium for social interaction online has been widespread even worldwide. Many benefits can be obtained by joining a social networking site like Facebook. Users can connect with their friends, be it new or old friends, family, and others without being hindered by distance. In addition, we can also take advantage of many entertainment features that are available for free; among them are quizzes, games, chat, and many others (Alfani, 2018). Facebook has an easy effective interaction tools with the diversity of features and participants (Sirivedin, Soopunyo, \& Srisuantang, 2018).

The most popular mobile application for photo hosting which is breaking popularity records across the world is Instagram (Wielgosz, 2017). Instagram is another social media used as an anti-corruption campaign media due to its unique features and the capability to keep and show digital photos so that the information becomes more interesting. The Instagram resources represent mediated user-generated memories in the form of qualitative and multimedia data, and the resulting prototype exploited photographs, titles, tags, comments, people, and dates. In these resources, the geographical information encoded within the Instagram data either consists of existing geographical references from geotags can be captured as part of the text mining process using the textual elements such as the titles or image captions (implicit) (Jones, Guido, \& Severo, 2018). The use of photos and videos further enriches the anticorruption campaign information delivered on Instagram. The idea behind the site is to share photographs and videos by using a hashtag (\#) so that other users can find the photographs. While similar to Facebook in the way that users can post photos online, unlike Facebook, Instagram offers several special filters that allow users to change the colors and resolutions of the photographs before they post them (Sheldon \& Bryant, 2016). The result shows that Instagram is popular among college students and women in particular. Personal characteristics such as gender, age, affordances on specific sites, and privacy concerns are predicted as social media preferences. Expanding upon the privacy paradox, researchers found that participants who preferred Twitter were more likely to have a public (vs. private) profile, higher levels of self-disclosure, and indicated to bridging social capital more. Participants who preferred Facebook had lower levels of self- disclosure, but higher levels of bonding social capital compared to those who preferred Instagram (Shane-simpson, Manago, Gaggi, \& Gillespie-lynch, 2018).

Anti-corruption campaigns carry out through social media with their characteristics and uniqueness that can support the goals of anti-corruption campaigns. The right segment adjusted with good communication techniques and the use of appropriate platforms will help achieve the objectives of the campaign. A consequence of "interactivity" and "participation" in the social media age is engagement connects interactivity and social media to produce User Generated Content (UGC) and creates a new engagement business model. Social media facilitate engagement. Features such as being able to access online activities easily, online forums, and real-time statistics make engagement more efficient ( $\mathrm{Wu}, 2018)$. Social media provides a significant avenue for stakeholder engagement crucial to ensure the loyalty and satisfaction of stakeholders who have valuable resources that can influence the business. However, not all social media posts generate the same amount of stakeholder engagement (Surucu-balci, Balci, \& Fai, 2020).

In the PERC ranking in 2018, Indonesia ranks third-worst in Asia after Vietnam and Cambodia from the 16 countries surveyed. In the best 1 to 10 worst standards, Cambodia is the lowest with a score (8.13), followed by Vietnam (7.90), Indonesia (7.57), India (7.25), and Thailand (7.13), and China (7.08). Singapore rank as the most efficient bureaucracy with a score of 1.90 , followed by Australia with 2.50 (https://www.cpib.gov. $\mathrm{sg} / \mathrm{research}$-room/political-economic-riskconsultancy, accessed 27 December 2018).

Based on figure 1 above, the researchers felt the need to research the Engagement and Action of Anti-Corruption Campaigns on Facebook and Instagram. Formulation of the research problem is how does the engagement and action of the anti-corruption campaign on social media of Facebook and Instagram.

The purpose of this study is to find out, analyze, and discuss aspects of engagement and action of anti-corruption campaigns on social media of Facebook and Instagram. From the research questions above, it can be stated that the engagement and action of respondents in anti-corruption campaigns on social media Facebook and Instagram are carried out by seeing and observing more. 


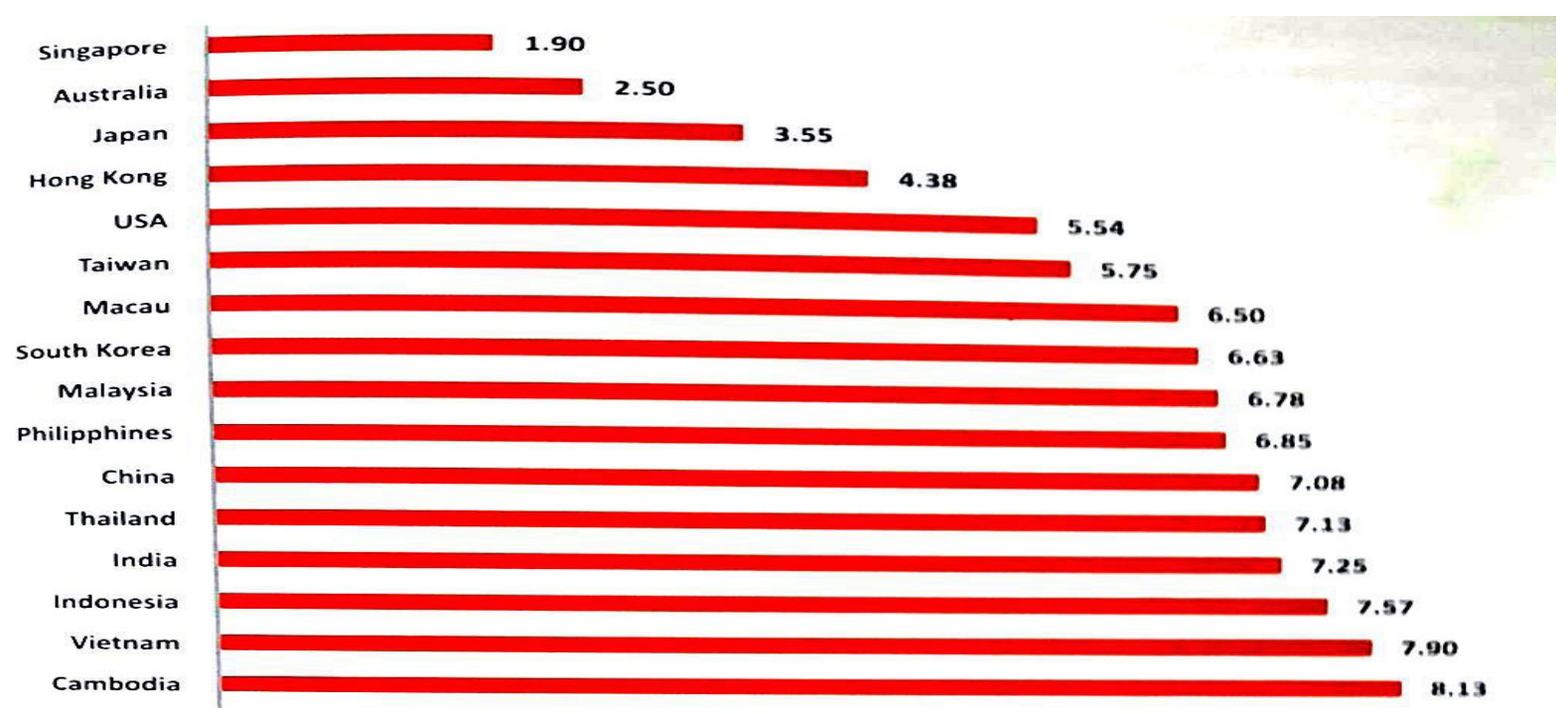

Figure 1: The 2018 PERC Ranking of Countries' Bureaucratic Performance Source: Team for Writing Anti-Corruption Education Books (Antikorupsi, 2018)

While, at the same time on Facebook, they are actively giving comments and results. This research can be stimulation for efforts to bridge public awareness of the importance of anti-corruption. The further implication of public awareness is that people will get a better knowledge of the importance of anti corruption and disseminate it to the community.

\section{Research methodology}

Noting the problem formulation and research objectives, the researchers determined the research method to be used was the survey method through descriptiveanalytical studies. The research design is applied through the following stages: 1) the researcher conducts a fact-finding to determine the appropriate research objectives and media; 2) the researcher observes the campaign activities carried out by the Corruption Eradication Commission; 3 ) the researcher sets the right frame of mind, references, and research methods; 4) researchers determine the population, sample, and data collection techniques; 5) the researcher examines the components of objective research; 6) researchers go to the field; 7) researchers conduct data collection and processing; 8) researchers report the findings and research results. Research informants/research subjects are those who understand the information of the research object as the doers as well as other people who understand the research object. The object of research is the anti-corruption campaign carried out by the KPK through Instagram and Facebook. The population in the study was 361,000 netizens from Instagram and 1,341,951 from Facebook. Sampling was taken using the Slovin formula with $a=0.1$ so that we got a sample of 100 netizens from Instagram and 100 from Facebook. The total sample was 200 netizens. The data collection technique was carried out through questionnaires, observation, and study of literature. The data analysis technique was done using descriptive tables with the percentage of research results.

Descriptive statistics or inferential statistics do data processing. Inferential statistics are used to analyze data by describing the collected data as it is. In processing data, the steps taken are selecting data, making coding books, coding sheets, calculating alternative frequency answers with percentages, and then making tabulations in the form of bar charts. After that, data analysis and interpretation are carried out. The formula used is $\mathrm{P}=\mathrm{F} / \mathrm{N} \times 100 \%$, where;

$\mathrm{P}=$ Percentage sought

$\mathrm{F}=$ Frequency (respondent's answer)

$\mathrm{N}=$ Number of cases (number of respondents) (Arikunto, 2011)

\section{Results and Discussion}

Engagement of Anti-Corruption Campaign on social media of Facebook and Instagram

Based on the data of engagement as 
shown in figure 2, the activities of respondents when they open the KPK page on Instagram are mostly reading the information, check out the messages and visualizations, but only a few of them sending comments and disseminating the information to their friends.

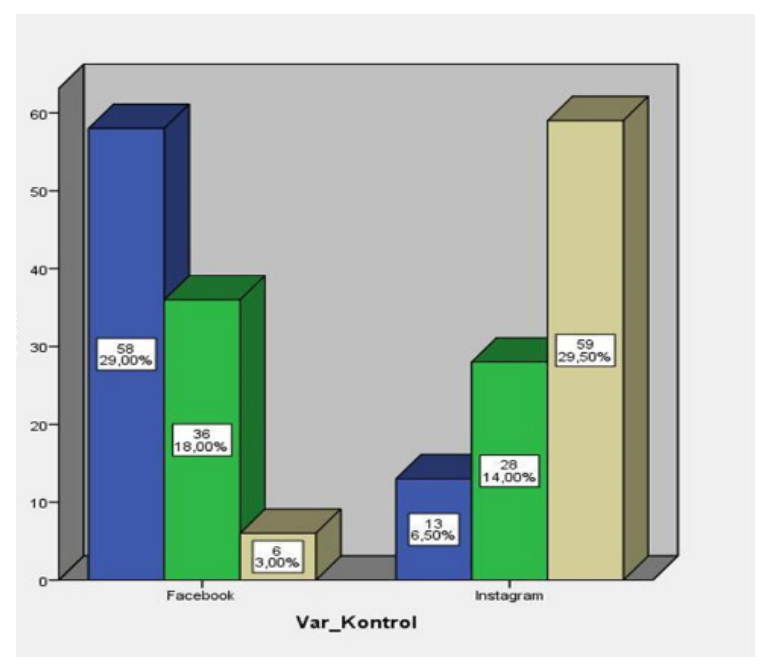

Figure 2: The results of the research of engagement

Other activities done are checking the page, clicking the like button, clicking links, etc. Meanwhile, there were only a few who gave comments and made hashtags.

Meanwhile, respondents on Facebook has different activities than those on Instagram. Respondents on Facebook mostly send comments, even spread the information on the KPK page to their friends. Other activities are giving rewards and more comments.

Based on the above description, it is obvious there are differences in respondents' activities on Facebook and Instagram when they open the KPK page. Respondents' behaviors on Facebook are more active in giving comments and rewards compared to those on Instagram where they only read the messages and see the visualizations.

\section{Description of the Analysis}

The results of the study related to engagement showed that the majority of respondents on Instagram only read information, observing messages and visualizations, and only a few giving comments and disseminating the information to friends. "Engagement means how much action take on the message we convey" (Adiwaluyo, 2014). The difference anti-corruption campaign messages on Instagram and Facebook is that it takes consideration for Instagram users to repost the information on their Instagram to remind the dangers of corruption. The Lexicon Webster Dictionary (Hamzah, 2007) defines corruption as follows:

The act of being corrupt or the state of being corrupt; putrefactive; decomposition. Putrid matter; moral perversion; depravity; a perversion of integrity; corrupt or dishonest, proceedings; bribery; a perversion from a state of purity; debasement, as of a language; a debased form of a word.

Corruption means rottenness, badness, dishonesty, can be bribed, immoral, deviation from holiness, insulting or slandering words/ sayings. While for Facebook users, they don't only read and observe, but also redistribute anti-corruption campaign messages on Facebook. As Muhtadi stated (Muhtadi, 2008) that," the campaign is carried out not only to socialize an idea, program, interest, or anything that is deemed necessary to be known to the public, but also to shape behavior" (Muhtadi, 2008). Facebook users have a better awareness than the Instagram user to redistribute the campaign as evidence of the involvement and responsibility of Facebook users of the dangers of corruption, meaning that the value system built by the KPK is following the system of respondents' values of Facebook users which shown by anti-corruption campaign messages.

\section{Anti-Corruption Campaign Action on Facebook and Instagram}

Table 1

Control Variable

* Cross tabulation Action Count

Action Total

Low Medium High

\begin{tabular}{lcccc}
$\begin{array}{l}\text { Facebook } \\
\text { Control } \\
\text { Variable }\end{array}$ & 1 & 6 & 93 & 100 \\
Instagram & 0 & 15 & 85 & 100 \\
Total & 1 & 21 & 178 & 200 \\
\hline
\end{tabular}

According to the research results on the action of respondents (figure 3 ), in general, respondents agreed to be aware of the danger of corruption and it is very important 
to understand it so that they are willing to participate in campaigning and inviting others to join the anti-corruption. While the results of research through Facebook are most of them strongly agree, and in general, agree related to questions about action for anti corruption.

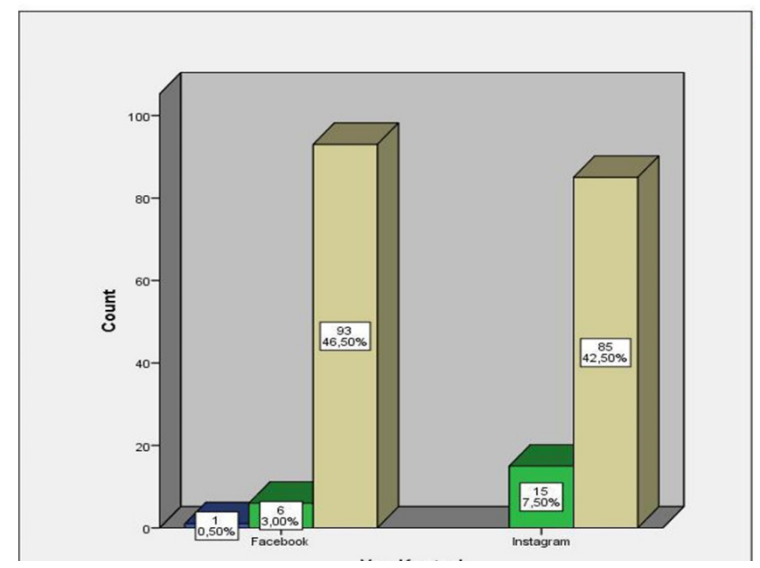

Figure 3: The results of the research of action

According to the research results on the action of respondents. Based on the findings in Table 1 , it is clear that respondents have realized and understand the dangers of corruption, and then they invite others to join the action of anti-corruption. The research shows encouraging results and shows a highvalue action related to anti-corruption issues.

\section{Description Analysis.}

The results of this study will have implications for the Corruption Eradication Commission's policy for the use and management of campaign media viewed from various factors, including the needs, goals, ease of access, management of message content for the ease of receiving messages, duration of exposure, and communication settings. If all this is considering, communication messages will likely be effectively conveyed and received.

This study has a weakness as well. It only studied the campaign media on Instagram and Facebook, rather than examining all types of social media such as Whatsapp, Line, Youtube, and blog used by the Corruption Eradication Commission. For the campaign activities, The Corruption Eradication Commission has used all forms of social media. The researchers hope that other researchers would complete this research by taking all social media used as the subject/object of the study.
Social media has a variety of functions such as interacting, building a reputation, and potentially moving the platform users to carry out multiple activities. Social media research has developed into various activities as described in the following statement,

Indeed, social media research has since burgeoned significantly along with the advancement of new communication technology. Scholars were seen to discuss varied topics including threats and privacy, users' identity and reputation, usage and gratification, social media as information avenue, effects of social media, and more (Nur atikah a. rahman, MD. salleh hj. hassan Mohd nizam osman, 2017).

Social media research has developed significantly along with the advancement of new communication technologies. Researchers have researched various topics including threats and privacy, user identity and reputation, use and satisfaction, social media as an avenue of information, the effects of social media, and more. This research resulted in the findings of users of Instagram and Facebook who do an anti-corruption campaign showing positive activities in helping the KPK program in spreading awareness of the dangers of corruption in Indonesia.

As stated by Adiwaluyo, the action at this last stage included the aspects measured that have reached the level of behavior. For example, how many audiences recommend the KPK campaign to other audiences. The indicator we used at this stage is the large number of votes obtained (Adiwaluyo, 2014). The results showed the majority of respondents on Instagram and Facebook had the awareness to redistribute anti-corruption campaign messages. However, when viewed in-depth, respondents on Facebook had a higher awareness than respondents on Instagram because the information obtained from the KPK about the anti-corruption campaign was more complete, in-depth, and supported by Facebook users who are generally more mature.

\section{Conclusions}

From the research conducted and research questions examined by the researchers, namely the engagement aspects of the anti-corruption campaign on social media Facebook and Instagram, respondents were more likely to see and observe only. At the same time, they were active on Facebook 
by sending comments and results.

Regarding the respondents' awareness about and the implementation of anticorruption campaigns on social media Facebook and Instagram, it showed that respondents have realized and understand the dangers of corruption and then invite others to conduct anti-corruption campaigns. The research shows encouraging results and high awareness values related to anti-corruption issues in Indonesia.

Netizen's involvement in anti-corruption campaigns that continuously displayed on social media by KPK has high ties to implement the content of the message with awareness. KPK should be able to manage video displays, flyers, photos, and others (visual and audiovisual), and provide various information to get users/readers' attention and be able to move them to do positive actions.

\section{Acknowledgment}

The researcher would like to thank the Rector of Bandung Islamic University, Chair of the Institute for Research and Community Service, Dean of the Faculty of Communication Sciences who has helped this research.

\section{References}

Adiwaluyo, E. (2014). Empat Tahap Mengukur Efektivitas Kampanye Media Sosial. Retrieved April 6, 2014, from http://www. the-marketeers.com/ archives/empattahap-mengukurefektivitas-kampanyemedia-sosial.html

Alfani, H. (2018). Peran facebook dalam kampanye politik pemilukada di kabupaten ogan kemiring ulu. Lugas, 2(1), 42-50.

Amin, K., Dziqie, M., Alfarauqi, A., \& Khatimah, K. (2017). Social Media, Cyber Hate, And Racism. Komuniti, 10(1), 3-10.

Antikorupsi, T. P. B. P. (2018). Pendidikan Antikorupsi untuk Perguruan Tinggi. Jakarta: Kementerian Riset, Teknologi, dan Pendidikan Tinggi Republik Indonesia.

Arianto, B. (2015). Kampanye Kreatif dalam Kontestasi Presidensial 2014, 19, 16-39.

Arikunto, S. (2011). Prosedur penelitian: suatu pendekatan praktek. Jakarta: Rineka Cipta.

Carr, C. T., \& Hayes, R. A. (2015). Social Media : Defining, Developing, and Divining Social Media : Defining, Developing, and Divining, (March), 37-41. https://doi.org
/10.1080/15456870.2015.972282

CPI-2017: Menera Korupsi di Tahun Politik - Transparency International Indonesia. (n.d.). Retrieved from https://ti.or.id/cpi2017-menera-korupsi-di-tahun-politik/

Dachroni, R., Muzwardi, A., Studi, P., Pemerintahan, I., Riau, K., Studi, P., ... Riau, K. (2017). The Analysis of AntiCorruption Behavior (Case Study: Batam Central Bureau of Statistic (BPS) Services, 2, 8-9.

Dirwan, A. (2016). The Effect of Education against Corruption In Indonesia.

Dragseth, M. R. (2019). Building Student Engagement Through Social Media Building Student Engagement Through Social Media. Journal of Political Science Education, O(0), 1-14. https://doi.org/1 0.1080/15512169.2018.1550421

Habibi, A. (2018). Doktrinisasi Anti Korupsi ; SALAM, Jurnal Sosial \& Budaya Syar-I, 5(1), 25-36. https://doi.org/10.15408/ sjsbs.v5i1.7903

Hamzah, A. (2007). Pemberantasan Korupsi Melalui Hukum Pidana Nasional dan Internasional. Jakarta: PT Raja Grafindo Persada.

He, T., Huang, C., Li, M., Zhou, Y., \& Li, S. (2020). Social Participation of the Elderly in China : The Roles of Conventional Media, Digital Access, and Social Media Engagement Authors and Affiliations: Telematics and Informatics, 101347. https://doi. org/10.1016/j.tele.2020.101347

ICW Kembali Menempati Peringkat Dunia dalam "Global Think Tank Index 2019." (2020). Retrieved from https://antikorupsi.org/ id/siaran-pers/icw-kembali-menempatiperingkat-dunia-dalam-"global-thinktank-index-2019"

Irawati. (2013). Kearifan Lokal dan Pemberantasan Korupsi dalam Birokrasi. Mimbar, 29(1), 101-110. Retrieved from file://C:/Users/Lenovo/Desktop/ AntiKorupsi (Jurnal ttg AntiKorupsi)/ Kearifan Lokal_Irawati.pdf

Jones, C. E., Guido, D., \& Severo, M. (2018). Towards place-based exploration of Instagram : Using co-design to develop an interdisciplinary geovisualization prototype cultural routes. Journal of Spatial Information Science, (17), 1-30. https:// doi.org/10.5311/JOSIS.2018.17.393

Khoerunnisa, Rissa; Abidin, Yusuf Zaenal; Ma'arif, A. A. (2018). Aktivitas Kampanye Public Relations dalam Mensosialisasikan Internet Sehat dan Aman. JH; Jurnal IImu Hubungan Masyarakat, 3(September), 79-96. 
Majmundar, A., Chou, C., Cruz, T. B., \& Unger, J. B. (2019). Addictive Behaviors Reports Relationship between social media engagement and e-cigarette policy support. Addictive Behaviors Reports, 9(July 2018), 100155. https:// doi.org/10.1016/j.abrep.2018.100155

Muhtadi, A. S. (2008). Kampanye Politik. Bandung: Humaniora.

Nur atikah a. rahman, MD. salleh $\mathrm{hj}$. hassan Mohd nizam osman, M. waheed. (2017). Research on the State of Social Media Studies in Malaysia: 2004-2015. Jurnal Komunikasi Malaysian Journal of Communication, 33(4), 38-55. Retrieved from https://pdfs.semanticscholar.org/8 840/663ae236927db0ca1feb01c40af1a7 4e8ca8.pdf

Nurfitri, A. D. (2017). Perilaku Pengguna Media Sosial beserta Implikasinya Ditinjau dari Perspektif Psikologi Sosial Terapan, 25(1), 36-44. https://doi.org/10.22146/ buletinpsikologi. 22759

Permana, F. Y. (2016). Perempuan dalam kampanye antikorupsi. Journal Aspikom, 3(0271), 399-413. Retrieved from file:///C:/Users/Lenovo/Desktop/ AntiKorupsi (Jurnal ttg AntiKorupsi)/ Perempuan dalam Kampanye Antikorupsi. pdf

Perreault; Marie-Catherine: Mosconi, E. (2018). Social Media Engagement : Content Strategy and Metrics Research Opportunities, (January). https://doi. org/10.24251/HICSS.2018.451

Savchenko, L., \& Subbot, A. (2018). Influence of Corruption on the Economic Development of Ukraine in Terms of Reformation, 4(3), 276-282.

Setiadi, W. (2018). Korupsi di Indonesia. Legislasi Indonesia, 15(3), 249-262. Retrieved from file:///C:/Users/ Lenovo/Desktop/AntiKorupsi (Jurnal ttg AntiKorupsi)/Korupsi di Indonesia_Wicipto Setiadi.pdf

Setiawan, B., \& Fithrah, D. S. (2018). Kampanye Gerakan Indonesia Diet Kantong Plastik Dalam Membentuk Persepsi Masyarakat Bandung. Jurnal Manajemen Komunikasi, 2(2), 102-117.

Shane-simpson, C., Manago, A., Gaggi, N., \& Gillespie-lynch, K. (2018). Computers in Human Behavior Why do college students prefer Facebook, Twitter, or Instagram? Site affordances, tensions between privacy and self-expression, and implications for social capital. Computers in Human Behavior, 86, 276-288. https:// doi.org/10.1016/j.chb.2018.04.041

Sheldon, P., \& Bryant, K. (2016). Computers in Human Behavior Instagram : Motives for its use and relationship to narcissism and contextual age. Computers in Human Behavior, 58, 89-97. https://doi. org/10.1016/j.chb.2015.12.059

Sirivedin, P., Soopunyo, W., \& Srisuantang, S. (2018). Effects of Facebook usage on English learning behavior of Thai English teachers. Kasetsart Journal of Social Sciences, 39(2), 183-189. https://doi. org/10.1016/j.kjss.2018.03.007

Skoric, M. M., Zhu, Q., Goh, D., \& Pang, N. (2015). Social media and citizen engagement : A meta-analytic review. https://doi. org/10.1177/1461444815616221

Surucu-balci, E., Balci, G., \& Fai, K. (2020). Social Media Engagement of Stakeholders : A Decision Tree Approach in Container Shipping, 115. https://doi.org/10.1016/j. compind.2019.103152

Ulya, C. (2016). The Educational Values of Anti-Corruption in The Textbook of Poetry Appreciation, 2(1), 794-802.

Voorveld, H. A. M., Noort, G. Van, Muntinga, D. G., Bronner, F., Voorveld, H. A. M., Noort, G. Van, ... Bronner, F. (2018). Engagement with Social Media and Social Media Advertising: The Differentiating Role of Platform Type Engagement with Social Media and Social Media Advertising : The Differentiating Role of Platform Type, 3367. https://doi.org/10.1080/0091336 7.2017.1405754

Wang, R., Kim, J., Xiao, A., \& Ju, Y. (2017). Networked narratives on Humans of New York : A content analysis of social media engagement on Facebook. Computers in Human Behavior, 66, 149-153. https:// doi.org/10.1016/j.chb.2016.09.042

Widyaningrum, H. (2018). Eksistensi Pemberantasan Korupsi dalam Perjanjian Investasi Internasional di Indonesia. Integritas, 4(2), 55-73. Retrieved from file:///C:/Users/Lenovo/Desktop/ AntiKorupsi (Jurnal ttg AntiKorupsi)/ Eksistensi Pemberantasan Korupsi.pdf

Wielgosz, M. (2017). Usefulness And Potential Benefits of Analyzing New Media From the Perspective of L. Manovich's Soft Technological Determinism - The Case of Instagram and Smartphone, 2, 6-13. https://doi.org/10.1515/sc-2017-0007

Wu, B. Y. (2018). Social media engagement in the digital age. https://doi. org/10.1177/0739532918796236 